Chirurgia (2021) 116: 75-88

No. 1, January - February

Copyright@ Celsius

http://dx.doi.org/10.21614/chirurgia.116.1.75

\title{
Native Valve Infective Endocarditis - the Postoperative Results and Role of the Endocarditis Team. A Single Center Experience
}

\author{
Adrian Molnar ${ }^{1,2}$, Diana Sacuil, ${ }^{1, *}$, Alexandru Oprea ${ }^{1,2}$, Catalin Trifan ${ }^{1,2}$, Horatiu Moldovan $^{3}$ \\ 'Department of Cardiovascular Surgery, Emergency Heart Institute for Cardiovascular Diseases, Cluj-Napoca, Romania \\ 2"Iuliu Hatieganu" University of Medicine and Pharmacy, Cluj-Napoca, Romania \\ 3"Titu Maiorescu" University, Bucharest, Romania
}

*Corresponding author:

Diana Sacui, MD

19-21 Motilor Street, 400001

Cluj-Napoca, Romania

E-mail: diana_sacui27@yahoo.com
Received: 03.01.2021

Accepted: 11.02 .2021

\section{Rezumat}

Endocardita infectioasă de valvă nativă: rezultate postoperatorii și rolul echipei de endocardită. Experiența unui singur centru

Context: Endocardita infecțioasă (EI) se poate prezenta sub aspecte destul de diferite. În consecință, managementul ei implică o abordare colaborativă între mai multe specialități. Am analizat momentul operator şi rolul „Echipei de endocardită” la pacientii cu EI.

Metode:Înregistrările medicale ale pacienților operați pentru IE în centrul nostru într-o perioadă de 18 ani au fost analizate retrospectiv pentru datele demografice, agentul cauzal, caracteristicile imagistice ale valvei afectate, extensia leziunilor sistemice şi rezultatele postoperatorii.

Rezultate:Vârsta pacienților a variat între 7 şi 84 de ani şi, în multe cazuri (55.88\%), etiologia a rămas neidentificată. Complicatiile postoperatorii precoce nu au fost semnificativ mai mari la pacienții operați în situații de urgență comparativ cu cei cu intervenție chirurgicală electivă. Rata generală a mortalitătii postoperatorii precoce a fost de $14.05 \%$, semnificativ mai mică în cazurile de chirurgie electivă $(p=0.001)$. Urmărirea pe termen lung a pacientilor operați între 2008 şi 2017 a arătat o rată de deces postoperator tardiv de 17.8\% (34 de pacienți).

Concluzii: Chirurgia de urgență pentru pacienții cu EI valvulară nativă oferă în majoritatea cazurilor o şansă bună de vindecare, în ciuda frecvenței relativ ridicate a complicațiilor postoperatorii şi a ratei de deces postoperator. Progresele în managementul 
pre- şi post-operator al pacienților cu EI, precum şi în tehnicile chirurgicale şi valvele protetice par să îmbunătățească şi mai mult rezultatele.

Cuvinte cheie: endocardita infecțioasă de valvă nativă, complicații post-operatorii, mortalitate postoperatorie

\begin{abstract}
Background:Infective endocarditis (IE) may present with quite different aspects. Consequently, it's management involves a collaborative approach between several specialties. We analyzed the timing of surgery and the role of the "Endocarditis Team" in patients with IE.

Methods: The medical records of patients operated for IE in our center during an 18-year period were retrospectively analyzed for the demographic data, causative agent, imagistic features of the affected valve and systemic lesion extension and postoperative results.

Results: Patients' age ranged between 7 and 84 years, and in many cases (55.88\%) the etiology remained unidentified. The early postoperative complications were not significantly higher in patients operated in emergency compared to those with elective surgery. The overall early postoperative mortality rate was $14.05 \%$, significantly lower in the elective surgery cases $(p=0.001)$. The long-term follow-up for patients operated between 2008 and 2017 showed a late postoperative death rate of $17.8 \%$ (34 patients).

Conclusions: Emergency surgery for patients with native valve IE provides in most cases a good chance for a cure, despite the relatively high frequency of postoperative complications and rate of postoperative death. The advances in pre- and post-operative management of IE patients, as well as in surgical techniques and prosthetic valves seem to further improve the outcome.
\end{abstract}

Key words: native valve infective endocarditis, postoperative complications, postoperative mortality

\section{Introduction}

In contrast to the improved quality of life, diagnosis methods and antibiotic therapy, infective endocarditis (IE) continues to affect a relatively large segment of the active population with an incidence of $3-10$ episodes / 100 000 person-years (mostly men aged between 70 and 80 years) (1). The persistence of high morbidity and mortality rates demonstrate that IE remains a major issue for health systems, and a particular provocation for cardiac surgeons.

The epidemiology of IE has significantly changed over the past few years in developed countries, showing that high risk groups are represented by patients with congenital heart disease (CHD), prosthetic device implants, invasive procedures, intravenous drug use, human immunodeficiency virus infection and diabetes mellitus; also, the patients affected are older than in the past (2). Clinical presentation is characterized by high rates of Staphylococcus aureus infection, cardiac complications, and embolic events (2). Regarding the IE treatment, early surgery has become the central component (2).

In patients on chronic hemodialysis, intravenous drug users and those with implantable electronic cardiac devices, right heart valves are more frequently affected, while left sided endocarditis is more common in patients with major comorbidities who undergo non-cardiac major surgery (3).

In recent decades, despite the major outcome improvement due to modern antibiotic 
and surgical treatments, IE remains a life threatening disease (4). The long term morbidity and mortality caused by late sequelae such as congestive heart failure, valve incompetence, and predisposition to recurrent infective endocarditis are becoming more important; also, the focus has shifted away from infections of native valves to endocarditis of prosthetic valves in the elderly and to endocarditis in users of injected drugs (4).

Due to the wide range of causative organisms, at-risk populations and underlying risk factors for infection, definitive studies of IE have been limited by its relative infrequency (5).

For patients with IE, delivery of optimal care requires an administrative infrastructure and the involvement of multiple hospital specialists, including cardiologists, surgeons, infectious disease physicians, microbiologists, nephrologists, neurologists, and radiologists (6).

Early discussion with the surgical team is important and is considered mandatory in all cases of complicated IE [i.e. endocarditis with heart failure (HF), abscess or embolic or neurological complications] (7). Therefore, the presence of an Endocarditis Team in all referral centers is crucial and has several important roles (7):

- To have meetings on a regular basis in order to discuss cases, take surgical decisions, and define the type of follow-up;

- To choose the type, duration and mode of follow up of antibiotic therapy;

- To participate in national and international registries, to publicly report the mortality and morbidity of their center.

In order to address the limitations shown by previous IE studies, and, more important, to assess the therapeutic means in a conclusive way, a prospective, multicenter procedure is required.

The study objectives were to analyze the results of surgical intervention related to operatory moment (emergency or elective), the role of the "endocarditis team" and the main clinical and imagistic characteristics of patients included in study.

\section{Material and Method}

The study included 306 consecutive patients operated for native valve infective endocarditis (IE) in the Heart Institute of Cluj-Napoca, Romania, between January 2001 and December 2018.

For the diagnosis of IE we used the modified Duke criteria and imaging techniques: echocardiography (trans-thoracic and transesophageal) and CT-scan (cerebral, coronary, abdominal) - for complete diagnosis of possible secondary manifestations of IE.

The medical records were retrospectively analyzed for the demographic data, the causative agent, the imagistic features of the affected valve and systemic lesion extension, the postoperative complications, and the early postoperative mortality. The identification of causative agent was made by positive blood cultures and / or positive valve cultures.

In all cases, the indication for emergency / urgency operation was established according to the current European Society of Cardiology (ESC) and American Heart Association (AHA) guidelines: progressive congestive heart failure, untreatable sepsis, peripheral or central emboli, echocardiographic evidence of large, friable vegetation. Besides valve replacement / repair, additional surgical procedures like coronary bypass, annuloplasty, septal defect closure etc. were performed, as necessary.

Regarding the timing of surgery, we defined interventions performed in the first 24 hours after diagnosis as emergency surgery, interventions performed between 24 hours and 7 days after diagnosis as urgent surgery, and interventions performed in more than 7 days after diagnosis as elective surgery. For a better assessment of therapeutic results, the patients were divided into two groups - one with emergency / urgency surgery, and one with elective surgery.

Starting from 2015, the surgical indication for emergency or elective intervention was established by the Endocarditis Team. In our institution, this team is composed by a cardiologist, a cardiac surgeon, an infectionist and an anesthesiologist. 
We also performed a long-term follow-up for patients operated between 2008 and 2017, regarding late postoperative complications and mortality. All survivors who agreed to participate (60 patients) were clinically and echocardiographically assessed. For the other patients, the data were collected from family members and / or family doctor.

\section{Statistical analysis}

Categorical data are presented as counts and percentages, and comparison between groups performed using chi-square test; continuous data are presented as mean \pm SD. Statistical significance is defined by a predetermined cutoff for probability (P-value) of 0.05 .

\section{Results}

Cases frequency (Fig. 1).

Demographic data of patients (Table 1, Fig. 2).

Endocarditis etiology (Fig. 3).

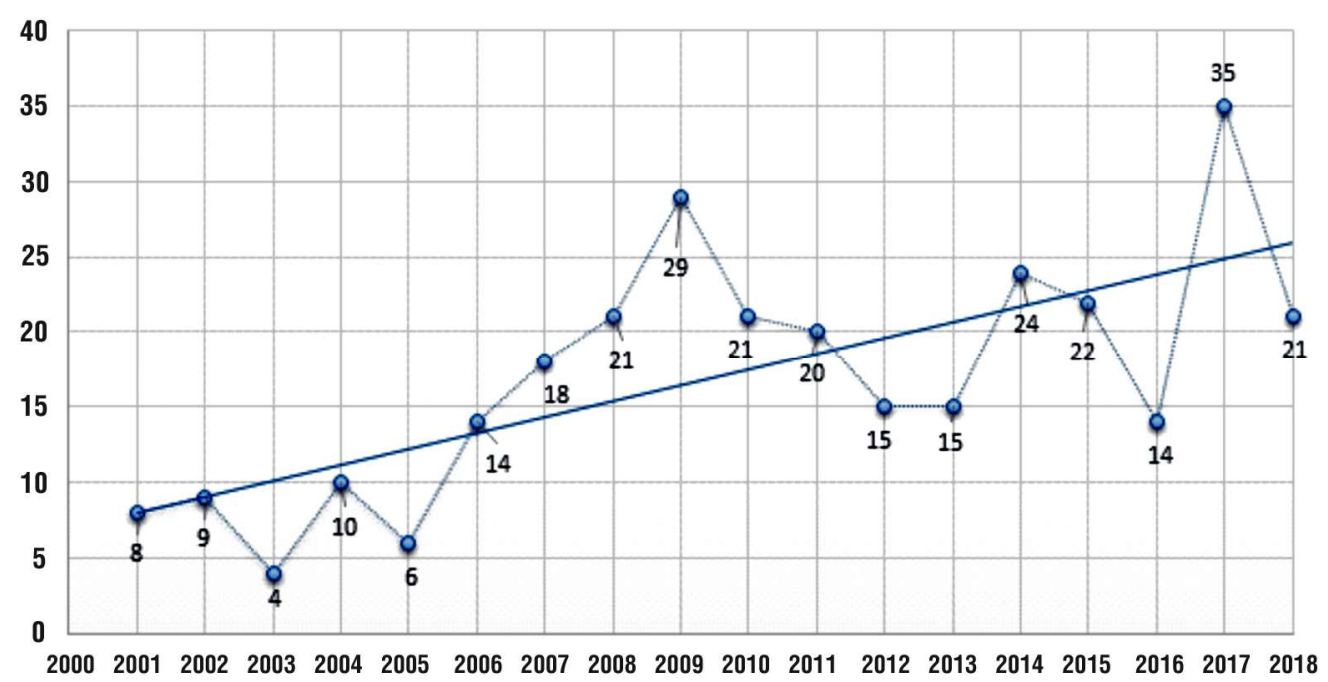

Figure 1. Frequency of native valve infective endocarditis (number of patients / year)

Table 1. Patients characteristics

\begin{tabular}{lc}
\hline Patients Characteristics & Number of Patients (\%) \\
\hline Age (average \pm SD) (years) & $53.45 \pm 14.57$ \\
\hline Gender - Males & $241(78.76 \%)$ \\
\hline Risk Factors & $293(95.75 \%)$ \\
\hline$\bullet$ Previous (known) valvular lesions & $160(52.28 \%)$ \\
\hline$\bullet$ History of complex medical procedures & $53(17.32 \%)$ \\
\hline$\bullet$ Presence of ICD & $20(6.53 \%)$ \\
\hline$\bullet$ History of rheumatic fever & $22(7.19 \%)$ \\
\hline$\bullet$ Congenital heart disease & $140(45.75 \%)$ \\
\hline$\bullet$ Other associated conditions (diabetes mellitus, neoplasm, end-stage renal disease) \\
\hline Affected Valve & $159(51.96 \%)$ \\
\hline$\bullet$ Aortic & $93(30.39 \%)$ \\
\hline$\bullet$ Mitral & $2(0.65 \%)$ \\
\hline$\bullet$ Tricuspid & $51(16.66 \%)$ \\
\hline - or More Valves & $99(32.35 \%)$ \\
\hline Systemic extension of Lesions
\end{tabular}

$\mathrm{SD}=$ standard deviation; ICD = intracardiac device; 


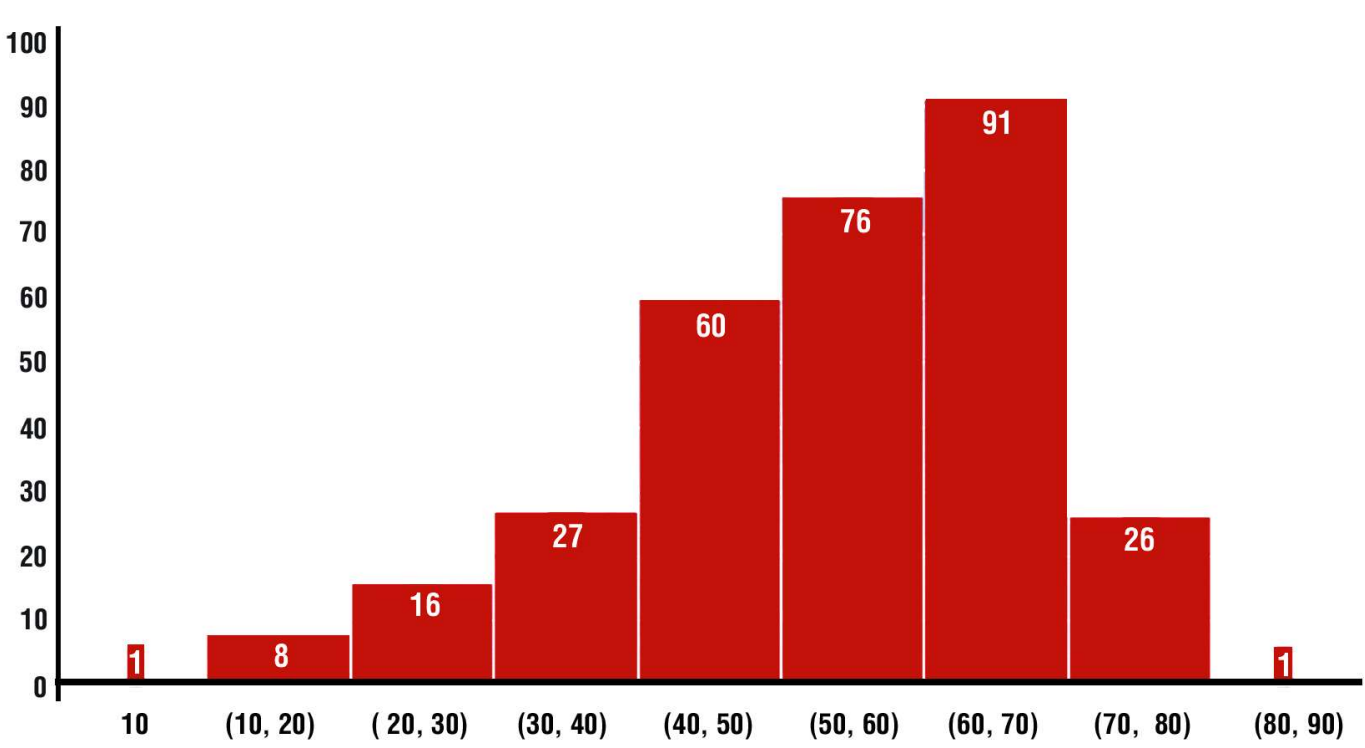

Figure 2. Distribution of patients by age range

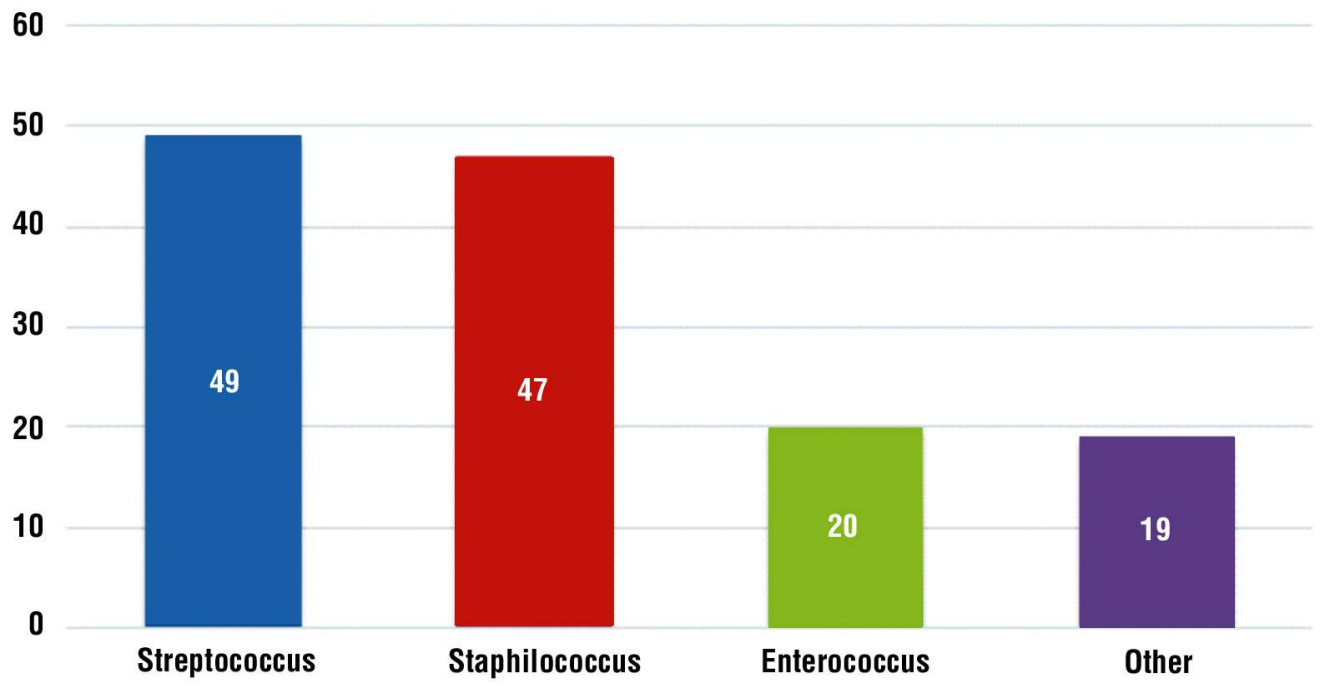

Figure 3. Type and frequency of causative agent for the patients with positive blood cultures

Positive blood cultures were determined in $44.11 \%$ of cases (135 patients), confirmed postoperatively by positive valve cultures only in $17.97 \%$ of cases (55 patients).

\section{Surgical treatment}

\section{Timing of surgery}

(emergency / elective interventions) (Figs. 4, 5)

Systemic extension of lesions was found in 99 patients $(32.35 \%)$ (Table 2$)$.

\section{Surgical therapy: procedure}

The surgical procedures included valve replacement (mechanical or biological), valve repair and associated procedures where needed (Fig: 6).

\section{Postoperative complications}

Types of early postoperative complications

Early postoperative complications occurred in 102 patients (33.33\%) (Fig. オ). 


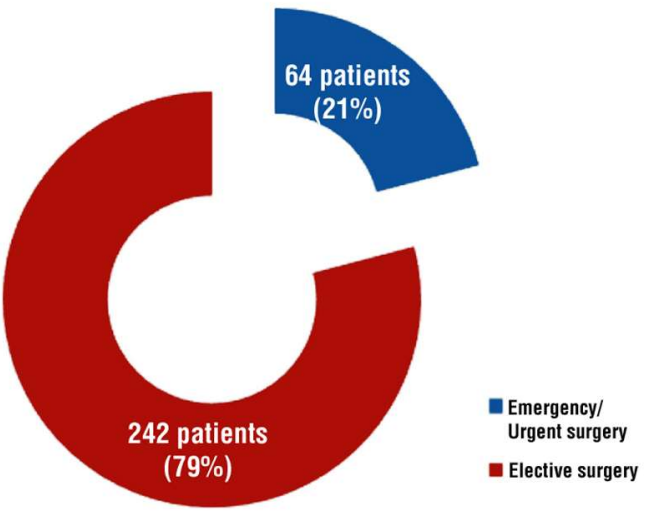

Figure 4. The timing of surgery (frequency of emergency / urgent and elective interventions)

\section{Postoperative complications}

Postoperative complications related to timing of surgery (Table 3).
Early postoperative mortality

(30 days after surgery)

The overall early postoperative mortality was $14.05 \%$ (43 patients).

\section{Causes of early postoperative mortality (Fig. 8)}

Early postoperative mortality related to timing of surgery (Table 3). Early postoperative mortality in patients with emergency / urgent surgery (Fig. 9).

\section{The long-term follow-up}

The long-term follow-up refers to patients operated in a ten-year period, between 2008 and 2017. Long-term survivors who consented to participate in the study $(\mathrm{N}=60)$ were clinically and echocardiographically assessed for a minimum of 6 -months period after inter-

Table 2. Presence of systemic lesions related to timing of surgery (CHI-squared Test):

\begin{tabular}{lcccc}
\hline Timing of surgery & $\begin{array}{c}\text { Presence of systemic } \\
\text { lesions }\end{array}$ & $\begin{array}{c}\text { Absence of systemic } \\
\text { lesions }\end{array}$ & Total & P - value \\
\hline Emergency / Urgent interventions & $20(31.25 \%)$ & $44(68.75 \%)$ & 64 & 0.832 \\
\hline Elective interventions & $79(32.64 \%)$ & $163(67.36 \%)$ & 242 & \\
\hline Total & 99 & 207 & 306 & \\
\hline
\end{tabular}

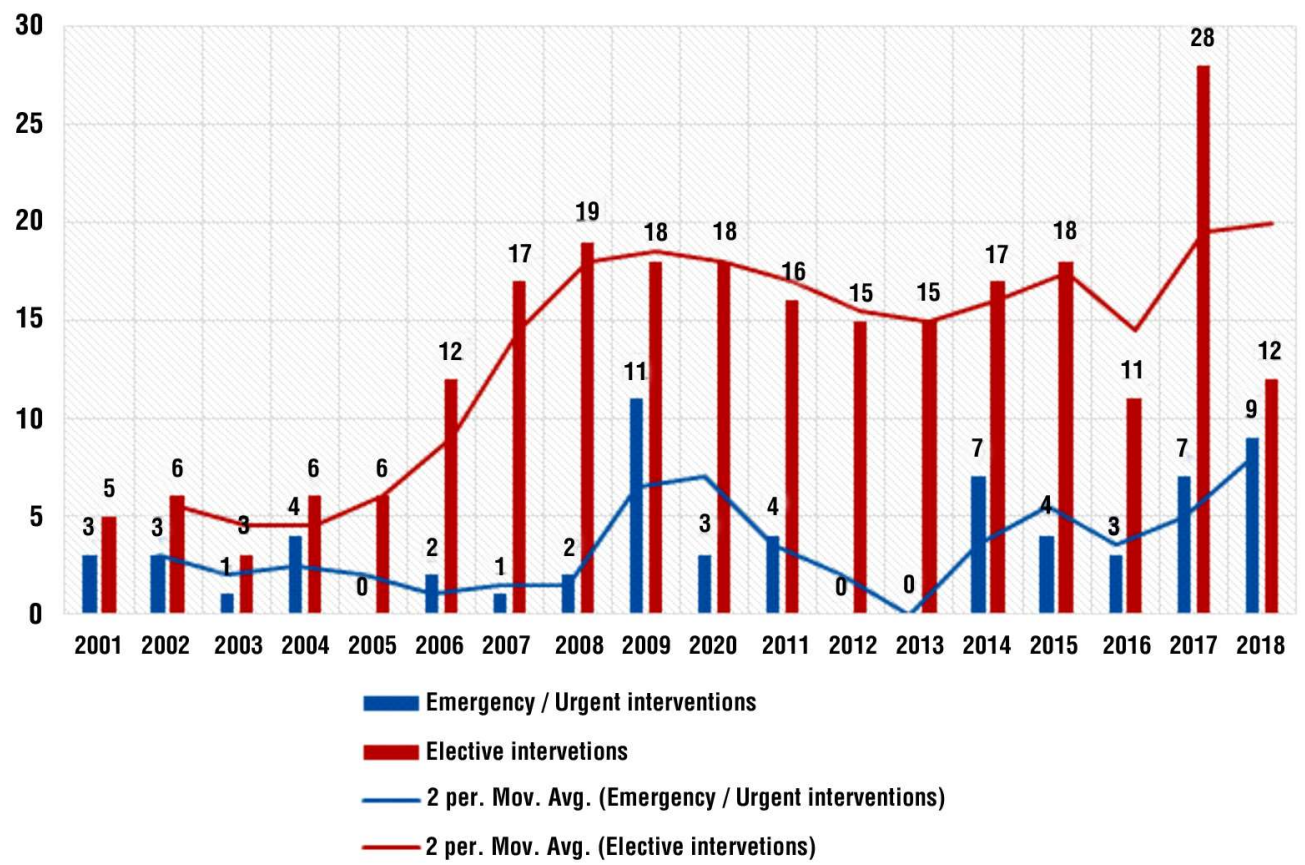

Figure 5. Frequency of emergency / urgent and elective interventions related to study period 


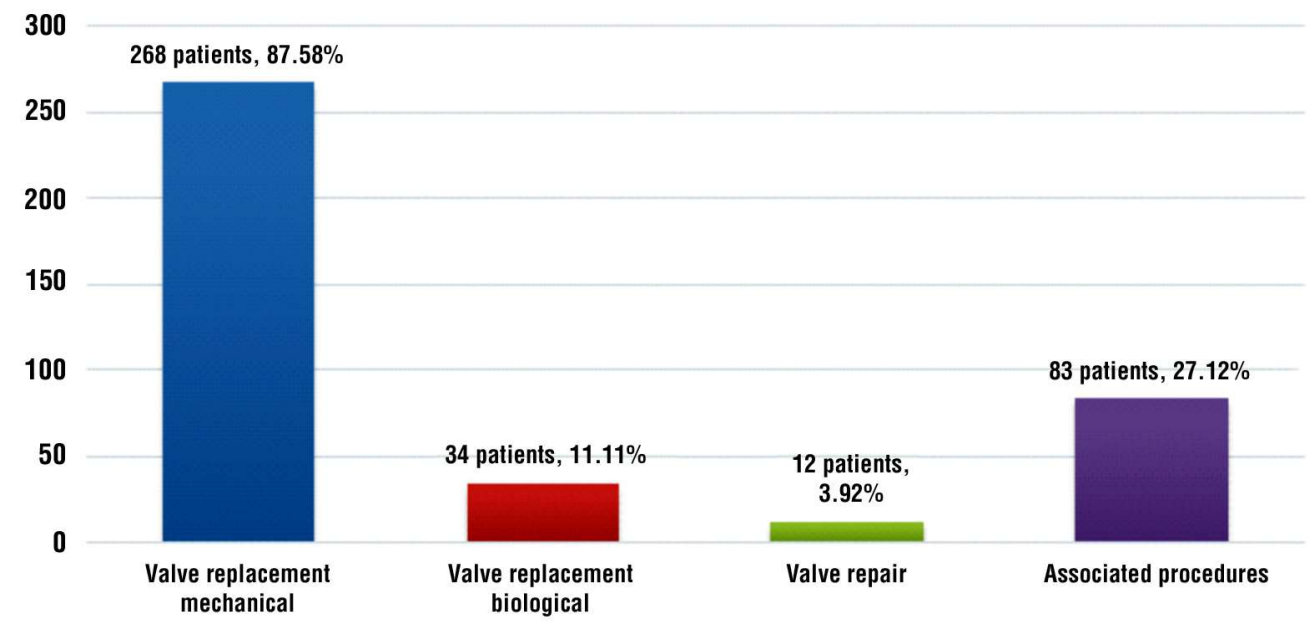

Figure 6. Frequency of different types of surgical interventions

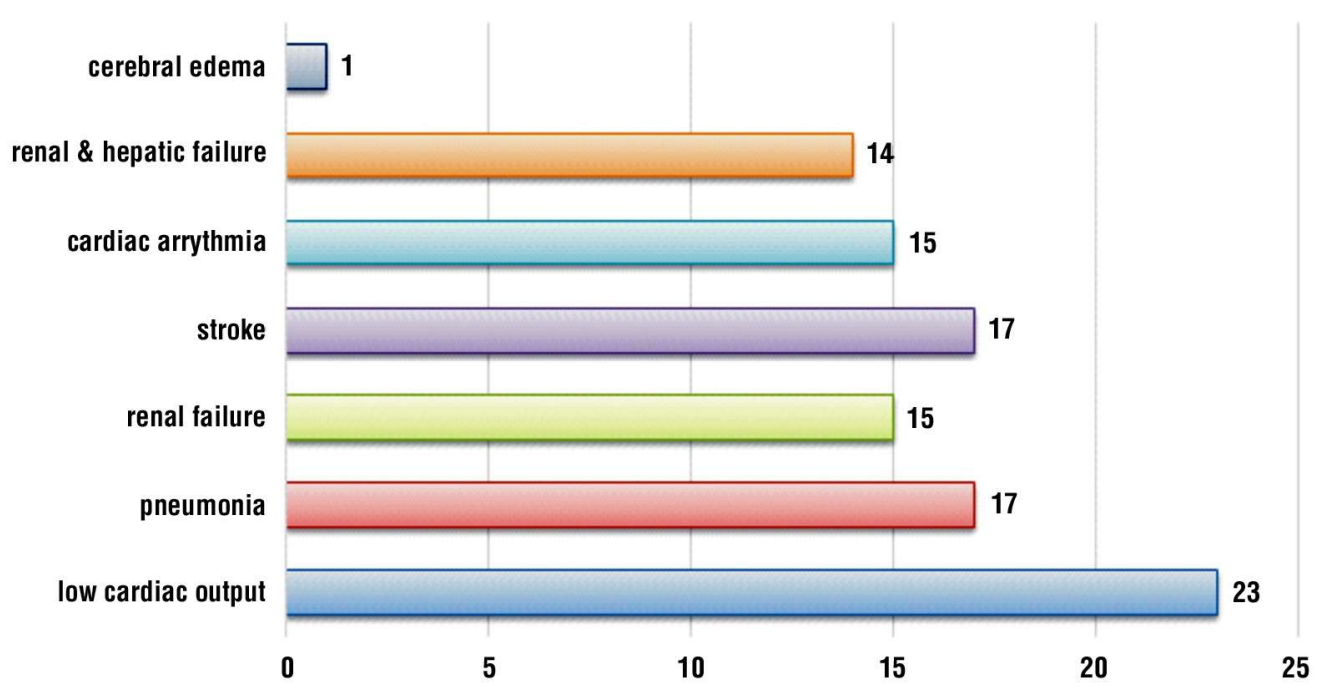

Figure 7. Early postoperative complications in the studied patients

vention (the patients who did not agree to patients we contacted their family doctor). The present for clinical assessment were contacted evaluation was performed according to a by phone and asked about the quality of life preliminary appointment, in the second half of and presence of symptoms; for non-reachable 2018 (Table 5).

Table 3. Frequency of postoperative complications related to the timing of surgery (CHI-squared Test)

\begin{tabular}{lcccc}
\hline Timing of surgery & $\begin{array}{c}\text { Presence of postoperative } \\
\text { complications }\end{array}$ & $\begin{array}{c}\text { Absence of postoperative } \\
\text { complications }\end{array}$ & Total & P - value \\
\hline Emergency / Urgent interventions & $19(29.69 \%)$ & $45(70.31 \%)$ & 64 & 0.486 \\
\hline Elective interventions & $83(34.30 \%)$ & $159(65.70 \%)$ & 242 & \\
\hline Total & 102 & 204 & 306 &
\end{tabular}




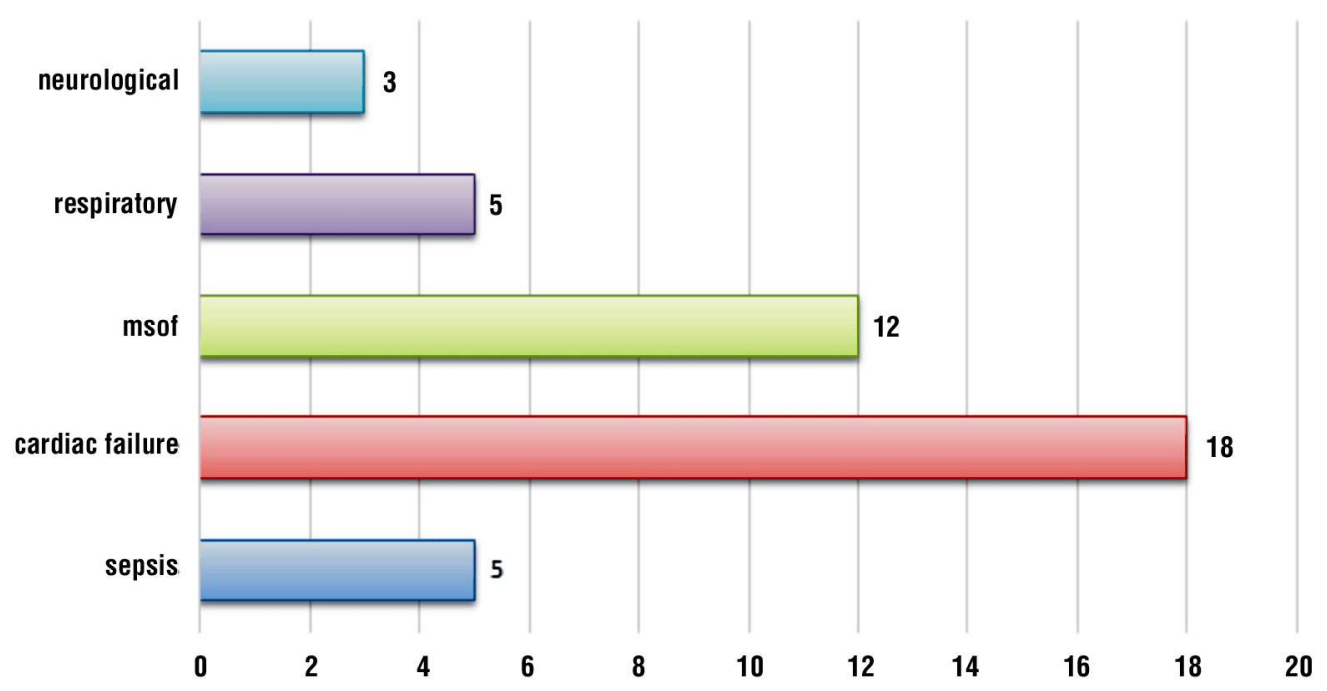

Figure 8. Incidence of early postoperative mortality causes msof $=$ multiple system and organ failure

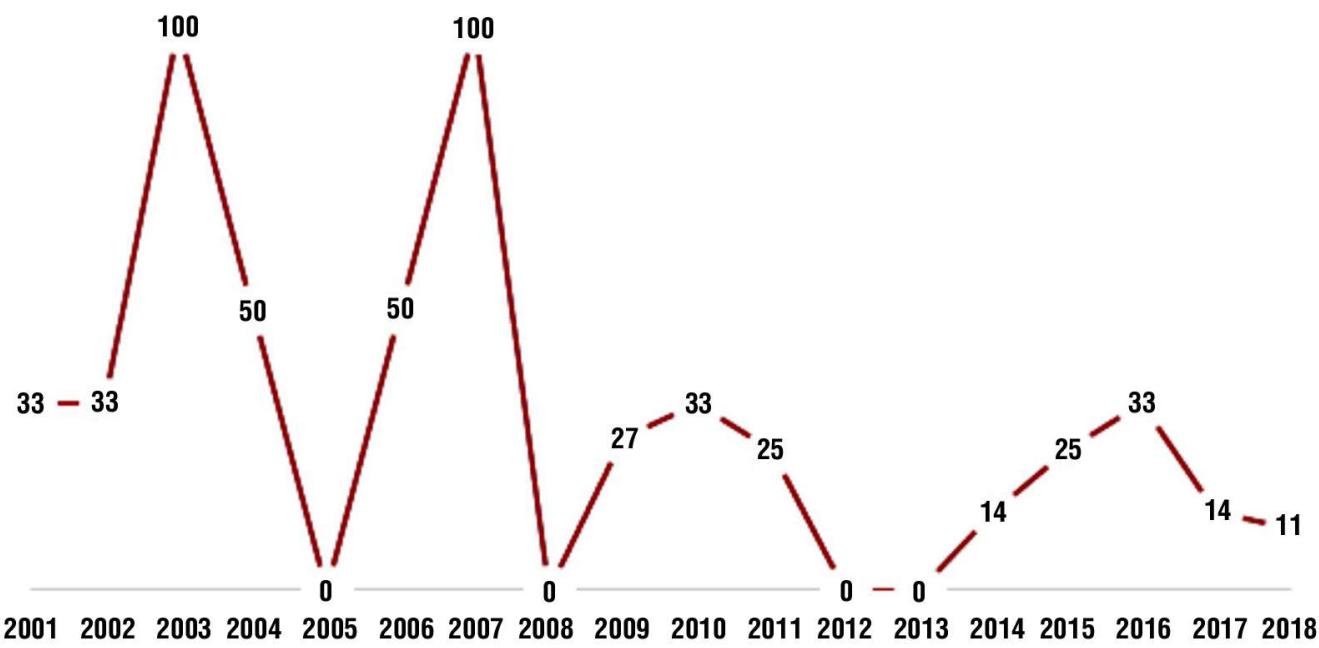

Figure 9. Frequency of early mortality cases in emergency / urgent surgery procedures

\section{Late postoperative death}

Late postoperative death (> 30 days after surgery) occurred in 34 patients (17.80\%). years (Fig. 10).

Table 4. Frequency of early postoperative mortality related to timing of surgery (CHI-squared Test)

\begin{tabular}{lcccc}
\hline Timing of surgery & $\begin{array}{c}\text { Postoperative mortality } \\
- \text { YES }\end{array}$ & $\begin{array}{c}\text { Postoperative mortality } \\
- \text { NO }\end{array}$ & Total & P - value \\
\hline Emergency / Urgent interventions & $17(26.56 \%)$ & $47(73.44 \%)$ & 64 & 0.001 \\
\hline Elective interventions & $26(10.74 \%)$ & $216(89.26 \%)$ & 242 & \\
\hline Total & 43 & 263 & 306 & \\
\hline
\end{tabular}


Table 5. Clinical and echocardiographical assessment at minimum 6 months after surgery

\begin{tabular}{lc}
\hline Characteristic & Number of patients (\%) \\
\hline NYHA Class I - II & $52(86.67 \%)$ \\
\hline Sinus cardiac rhythm & $53(88.33 \%)$ \\
\hline Functional prosthesis & $59(98.33 \%)$ \\
\hline Without para-prosthetic leak & $57(95.00 \%)$ \\
\hline Without intra-prosthetic leak & $52(86.67 \%)$ \\
\hline Without prosthetic vegetations & $60(100 \%)$ \\
\hline Left ventricle ejection fraction (mean) & $54.75 \%$ \\
\hline
\end{tabular}

$\underline{\text { Influence of type of surgery and surgery date on }}$ long-term survival (Table 6)

\section{Role of the Endocarditis Team (Table 7, 8)}

\section{Discussion}

According to the latest statistics released by EuroStat in 2018, among European countries Romania records one of the greatest incidences

Table 6. Long-term survival correlated to type of surgery (CHI-squared Test)

\begin{tabular}{|c|c|c|c|}
\hline Timing of surgery & $\begin{array}{l}\text { Long-term survival } \\
\text { (> } 6 \text { months } \mathrm{p} .0 .) \\
\text { ( } \mathrm{N}=157 \text { patients) }\end{array}$ & $\begin{array}{l}\text { Late postoperative death } \\
\qquad(N=59 \text { patients) }\end{array}$ & $P$ - value \\
\hline $\begin{array}{l}\text { Emergency/ Urgent interventions } \\
(\mathrm{N}=52 \text { patients) }\end{array}$ & $32(61.54 \%)$ & $20(38.46 \%)$ & 0.038 \\
\hline Elective interventions ( $\mathrm{N}=164$ patients) & $125(76.22 \%)$ & $39(23.78 \%)$ & \\
\hline
\end{tabular}

Table 7. Influence of collaborative approach (Endocarditis Team) on timing of surgery

\begin{tabular}{|c|c|c|c|}
\hline Timing of surgery & $\begin{array}{c}\text { Period: } 2001 \text { - } 2014 \\
\text { (without Endocarditis Team) }\end{array}$ & $\begin{array}{c}\text { Period: } 2015 \text { - } 2018 \\
\text { (with Endocarditis Team) }\end{array}$ & $P$ value \\
\hline Emergency / Urgent surgery & $41(19.16 \%)$ & $23(25.0 \%)$ & 0.249 \\
\hline Elective surgery & $173(80.84 \%)$ & $69(75.0 \%)$ & \\
\hline$\overline{\text { Total }}$ & $214(100 \%)$ & $92(100 \%)$ & \\
\hline
\end{tabular}

Table 8. The influence of the Endocarditis Team on early postoperative mortality in patients with emergency / urgent surgery

\begin{tabular}{lccc}
\hline $\begin{array}{l}\text { Postoperative results for emergency / } \\
\text { urgent surgery }\end{array}$ & $\begin{array}{c}\text { Period: 2001 - 2014 } \\
\text { (without Endocarditis Team) }\end{array}$ & $\begin{array}{c}\text { Period: 2015 - 2018 } \\
\text { (with Endocarditis Team) }\end{array}$ & P value \\
\hline Early postoperative death - YES & $13(31.70 \%)$ & $4(17.40 \%)$ & 0.213 \\
\hline Early postoperative death - NO & $28(68.30 \%)$ & $19(82.60 \%)$ & $23(100 \%)$ \\
\hline Total & $41(100 \%)$ & 23 & \\
\hline
\end{tabular}

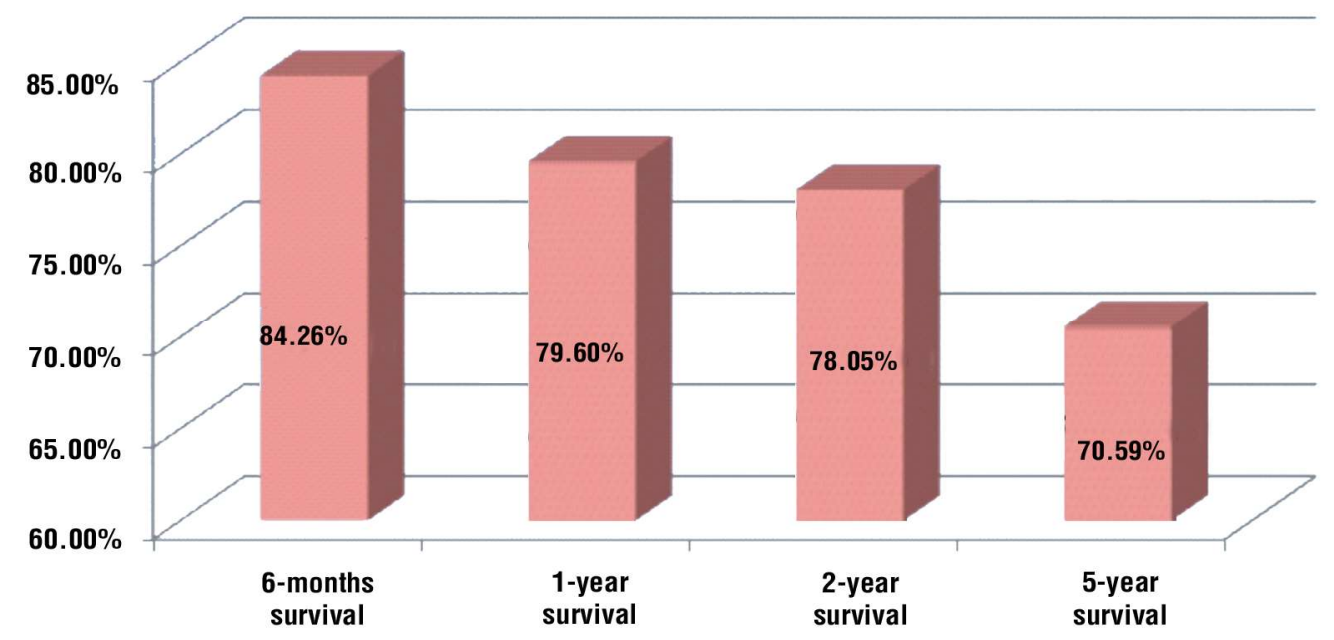

Figure 10. Evolution of postoperative survival rate

(number of survivors at the end of follow-up period / year of operation): 
of cardiovascular diseases, and occupies the second place regarding the per cent of total deaths caused by diseases of the circulatory system (8).

Infective endocarditis (IE) is a rare disease, but its impact is significant. It affects 3 to 10 per 100,000 per year in the population at large, and epidemiological studies suggest that the incidence is rising (6).

In a review of twelve small populationbased studies in Europe and Olmsted County, Minnesota the authors observed an acceleration of the trend in IE incidence; the review found rates (per 100,000) of 1.4-1.8 during the 1970 s and 1980s (with one outlier), rising to $2.2-4.9$ during the $1990 \mathrm{~s}$ (9). The same review found that IE is much more common than previously believed and continues to increase due to the increasing incidence among individuals 50 and older (9). In our study, the observed frequency had a moderate but persistent increasing tendency over the years (as shown in Fig. 1), with a "peak" of 35 patients in 2017. The mean age of patients was 53.45 years; the distribution of patients according to age groups showed a majority of cases (227 patients $-74.2 \%$ ) ranged between 40 and 70 year-old. We also noticed the male gender majority $(78.76 \%)$, consistent with many other studies.

Even if IE may be initially misdiagnosed due to patients presentation to different hospital specialties, data from hospital episode records only the discharge diagnosis and should therefore reflect as accurately as possible the actual number of cases treated (10). As the diagnosis of IE is sometimes uncertain, some cases will undoubtedly have been missed and others will have been erroneously labeled as endocarditis (10).

The main risk factors for native valve IE are nowadays considered to be increased longevity, increased exposure to nosocomial bacteremia, use of iv drugs, HIV infection, mitral valve prolapsed (1).

In the patients included in this study, the most frequently encountered risk factors were previous valvular lesions (95.75\%), a history of complex medical procedures (52.28\%) and other associated conditions like diabetes mellitus, neoplasms, or end-stage renal disease $(45.75 \%)$, followed by the presence if ICD $(17.32 \%)$ and congenital heart diseases (7.19\%).

Regarding the different types of cardiovascular implantable electronic devices (CIEDs), results from some studies suggest that implantable cardioverter-defibrillators are associated with a greater risk of infection than are permanent pacemakers. The risk of infection associated with epicardial systems is similar to that associated with transvenous systems and is estimated to be approximately $2 \%$ at 5 years after implantation (11).

The decline of rheumatic heart disease and advances in medicine through the $20^{\text {th }}$ century (especially the development of antibiotic drugs) opened the way for a change in the risk factor profile, patient demographic characteristics, and the microbiology of IE (6). Prosthetic valve replacement, hemodialysis, venous catheters, immunosuppression, and intravenous (IV) drug use became the principal risk factors, the average patient was older and frailer, with increasing comorbidities, and staphylococci overtook oral streptococci as the most frequent causative organism (6). Currently, IE has continued to evolve such that it is now health care-acquired in $>25 \%$ of cases, while advances in cardiology have driven further changes in the patient demographics and manifestations of the disease (6).

In cases with identified causative agent, the most frequent (49 patients) was Streptococcus, followed by Staphylococcus (47 patients). We also noticed a relatively high incidence of Enterococcus infections (20 patients), possibly related to an increasing number of endoscopic procedures in the recent years.

The previous studies conducted in our Institute showed a change over time in the etiologic spectrum in patients operated for subacute IE. Thereby, one study that assessed the patients operated between 2000 and 2011 found a frequency of $37 \%$ for Streptococcus, $31 \%$ for Staphylococcus and 16\% for Enterococcus. Another study, regarding patients operated for IE between 2010 and 2017, showed an inversion 
of the first and second places, with an increase of cases positives for Staphilococcus (31\%) and a decrease in Streptococcus cases (20\%), the third place still being occupied by Enterococcus (8\%).

The persistence of a large number of cases with negative blood cultures remains hard to explain. We consider that delayed medical presentation and previous empirical antibiotherapy, by self-medication or prescribed by family doctors without a specialist recommendation, could be the main causes for the higher percentage of undetermined etiology cases compared to the average reported by experienced centres from Europe and the rest of the world, where this percentage do not surpass $10-15 \%$ (according to the 2020 ESC guideline on Valvular Disease).

Due to usual association with a higher incidence of serious complications, a more complicated surgical procedure, or death, early diagnosis is essential in perivalvular IE (1).

Infection's extension to perivalvular structures signifies a poor prognosis in the evolution of the disease: it may result in endothelial erosion, perivalvular abscess, mycotic aneurysm, and intracardiac fistulae (13). In our study group, the most affected valve was the aortic valve (159 of 306 patients), and $32.35 \%$ of patients presented with systemic lesions due to endocarditis. When comparing the patients operated in emergency with those with elective surgery, we found no statistically significant difference regarding the presence of systemic lesions (uncontrolled infection).

In our center, the indication for emergency / urgent surgical intervention was based rather on the hemodynamic instability of patient than on the presence of systemic lesions before the initiation of Endocarditis Team in 2015; after that date, in accordance with the new guidelines, the collaborative approach (especially with the infectious disease specialist), resulted in increased emergency / urgent surgery indications (from $19.16 \%$ before 2015 to $25 \%$ after 2015 ).

There is no evidence for proven benefits of delayed surgical therapy in native valve IE, especially if the diagnosis is quickly established. The surgical technique applied to our patients was mainly represented by valve replacement (mechanical or biological), with associated procedures when needed; in a few cases we performed valve repair (3.92\%). We found no difference in the early postoperative complications rate between mechanical and biological valve replacement.

Regarding the timing of surgery, we defined emergency / urgency interventions as surgery performed within days after diagnosis (emergency: < 24 hors; urgency: 24 hours - 7 days), with their specific indications in IE: cardiogenic shock and persistent pulmonary edema. Depending upon tolerance of the valve lesion and if there are no other indications for surgery, medical treatment under careful clinical and echocardiographic surveillance is recommended, followed by elective surgery after resolution of the infection. In the last years of the study we noticed an increased proportion of emergency interventions, probably due to a reduction of time frame between diagnosis and surgery.

In our patients, the most frequent postoperative cardiac complications were represented by low cardiac output (23 patients) and cardiac arrhythmias (15 patients); meanwhile, there was a number of extra-cardiac early postoperative complications, with relatively high incidence of pneumonia, stroke and renal failure. We assessed the frequency of early postoperative complications related to the timing of surgery (emergency or elective surgery) and we did not find a significantly higher number of early complications in patients who benefited from emergency / urgent interventions $(\mathrm{P}$-value $=0.486)$. In the elective surgery group, 83 of 242 patients (34.29\%) experienced one or multiple early postoperative complications.

Regarding the embolic events (EE), there are studies (14) that concluded they are the most frequent extra-cardiac complication, with an incidence of symptomatic EE ranging from 10\% to $50 \%$, affecting mainly the central nervous system and therefore worsening prognosis. The treatment options are also affected, as surgery is indicated to prevent them (14). Also, a recent study showed that early surgery significantly 
reduces EE occurrence (15).

Despite the medical and surgical advancements in the treatment of patients with acute infective endocarditis (IE), neurologic complications remain problematic and can arise through various mechanisms consisting of stroke or transient ischemic attack, cerebral hemorrhage, mycotic aneurysm, meningitis, cerebral abscess, or encephalopathy (16). Worsening of neurological status during cardiac surgery after the onset of cerebral embolism is rare, therefore, if indicated, surgery should not be withheld, except in cases involving neurological symptoms and documented intracerebral bleeding (17).

Inclusion of these patients in cardiovascular rehabilitation programs might bring further benefits, along with the reduction of cardio-vascular risk factors and improving the quality of life (18).

Most studies suggest that combined medical-surgical treatment leads to reduced short term mortality in both prosthetic and native valve infective endocarditis (4).

However, despite advances during the past century in diagnosis, medical therapy and surgical treatment, mortality rates have not changed substantially in the past 25 years. The current in-hospital mortality rate for patients with IE is $15 \%$ to $20 \%$, with 1 -year mortality approaching $40 \%$ (5).

In our study, the overall early postoperative mortality rate (within 30 days after surgery) was $14.05 \%$ (43 patients), with cardiac failure as the main cause (18 patients - 41.86\%) followed by MSOF (multiple system and organ failure) (12 patients - 27.9\%); the other causes were represented by sepsis (11.63\%), respiratory failure (11.63\%) and neurological deterioration (6.97\%). The early postoperative death rate was significantly higher in patients who underwent emergency surgery compared to those electively operated $(\mathrm{P}=0.001)$.

The use of transesophageal echocardiography and the more accurate diagnostic criteria contributed to contemporary advance in the care of patients with IE; nevertheless, the in-hospital mortality rates maintain high (15 - 20\%). Thus, early identification of patients who are at high risk of death or complications of IE may offer the opportunity to improve the outcome of this disease (19).

The host-pathogen interaction in IE could be indicated by some factors like diabetes mellitus, S aureus infection, acute physiological severity and embolic events; those constitute early, independent determinants of in-hospital death. Still, early echocardiographic information, did not predict outcome; instead, it offers a means of early risk stratification of patients with IE and thus may identify higherrisk patients for more aggressive treatment or interventions (19).

In our study, the independent predictors for early postoperative mortality were older age, comorbidities, bi-valvular endocarditis, and Staphylococcal infection.

Hasbun et al found that cardiac surgery was an independent predictor of 6-month survival in a subset of patients with complicated left-sided IE (20).

Even if nowadays trends are toward earlier diagnosis and surgical intervention, the 1-year mortality from IE has not improved in over 2 decades (6).

As a part of the study, we performed a longterm follow-up for patients operated in a ten-year period, between 2008 and 2017. Longterm survivors who consented to participate in the study (60 patients) were clinically and echocardiographically assessed for a minimum of 6-months period after intervention.

According to the 2015 ESC Guidelines for the management of infective endocarditis (7), this is a disease that needs a collaborative approach for several reasons. First, IE is not a single disease, but rather may present with very different aspects depending on the first organ involved, the underlying cardiac disease (if any), the microorganism involved, the presence or absence of complications and the patient's characteristics. Second, a very high level of expertise is needed from practitioners from several specialties, including cardio-logists, cardiac surgeons, ID specialists, microbiologists, neurologists, neurosurgeons, experts in CHD and others. Finally, about half of the patients with IE undergo surgery during the hospital course. 
Introduction of a formalized multidisciplinary team approach in Italy, defined by initial evaluation within $12 \mathrm{~h}$, early surgery (within $48 \mathrm{~h})$ if indicated, and weekly review, led to a reduction in in-hospital ( $28 \%$ vs. $13 \%$; $\mathrm{p}=0.02)$ and 3 -year ( $34 \%$ vs. $16 \% ; \mathrm{p}=0.0007)$ mortality, despite patients being older and having more comorbidities (21). Similarly, a French multidisciplinary team approach to standardizing care, including antibiotic protocols and indications for surgery, reduced 1 -year mortality from $18.5 \%$ to $8.2 \%(22)$.

The importance of early surgery in improving patient outcomes and mortality is supported by some studies (5) suggesting that nearly $50 \%$ of patients with IE undergo surgery. More research also needs to focus on stroke prevention (eg, surgical therapy for vegetations), the identification of the most effective therapy (eg, the role of new antibiotics and combination treatment) (5).

In our study, we noticed an increase in the number of cases - $25.0 \%$ - operated in emergency / urgency in the last years (2015 2018), after implementation of Endocarditis Team in our service, but without statistical significance $(\mathrm{P}=0.249)$ compared to $19.16 \%$ in previous 14 years of the study. We also observed a non-significant reduction in mortality rate for patients operated after 2015 $-17 \%$, from $32 \%$ before $2015(\mathrm{P}=0.213)$.

Current guidelines widely recommend the surgical management for complicated leftsided IE; early surgery is strongly indicated for patients with infective endocarditis and congestive heart failure, but the indications for surgical intervention to prevent systemic embolism remain to be defined (23). Also this study emphasize the role of early surgery (compared to conventional treatment) in reducing the composite end point of death from any cause or embolic events by effectively reducing the risk of systemic embolism among patients with infective endocarditis and large vegetations (23).

\section{Study Limitations}

Our hospital-based analysis may underestimate the incidence of IE in general population. Some IE patients may die prior to a hospital admission or (rarely) be diagnosed and treated without being hospitalized.

Being an observational study of patients from a referral center with cardiac surgical programs, the study population is unlikely to be a true population-based sample, thereby limiting epidemiologic deductions.

It could be possible that patients transferred from other health care facilities would represent a different population than those who presented directly to study center. In particular, the former group may have more complicated disease and greater indications for surgery. The study did not address the long-term follow-up of patients, thereby limiting the ability to assess the outcome beyond initial admission.

\section{Conclusions}

Particularly in recent years, IE became a disease with a more acute presentation than previously described and is more frequent in patients with previous health care exposure. The main efforts should be oriented towards adequate treatment of $\mathrm{S}$ aureus bacteremia and identification of patients with high risk for complications. Emergency / urgent surgery for patients with native valve IE provides in most cases a good chance for a cure, despite the relatively high frequency of early postoperative complications and the rate of early postoperative death. The advances in pre- and postoperative management of IE patients, as well as in surgical techniques and prosthetic valves seem to further improve the short- and long-term results.

\section{Conflicts of Interest and Source of Funding}

None declared for all authors. This work was not financially supported by any person or institution.

\section{Ethical Policy}

During this study, the procedures followed 
were in accordance with the ethical standards of the responsible committee on human experimentation (institutional and national) and with the Helsinki Committee for Human Rights. Consequently, the study obtained the approval from The Ethical Commission of our institution.

\section{References}

1. Molnar A, Sacui D, Manole S, Radulescu A, Beyer R. The value of transthoracic and transesophageal echocardiography for the diagnosis of the native aortic infective endocarditis valve complications: a case report and literature review. Med Ultrason. 2016; 18(2):253-6.

2. Xu H, Cai S, Dai H. Characteristics of infective endocarditis in a tertiary hospital in East China. PLoS ONE. 2016;11(11): e0166764.

3. Moldovan H, Popescu D, Buliga T, Filip A, Antoniac I, Gheorghita D, Molnar A. Gastric adenocarcinoma associated with acute endocarditis of the aortic valve and coronary artery disease in a 61-yearold male with multiple comorbidities - combined surgical management - Case report. Medicina. 2019;55:242.

4. Netzer ROM, Altwegg SC, Zollinger E, Täuber M, Carrel T, Seiler C. Infective endocarditis: determinants of long term outcome. Heart. 2002;88(1):61-6.

5. Murdoch DR, Corey GR, Hoen B, Miro JM, Fowler Jr VG, Bayer AS, et al. Clinical presentation, etiology, and outcome of infective endocarditis in the 21st Century. The International Collaboration on Endocarditis-Prospective Cohort Study. Arch Intern Med. 2009; 169(5):463-73.

6. Cahill TJ, Baddour LM, Gilbert G, Hoen B, Salaun E, Pettersson GB et al. Challenges in infective endocarditis. J Am Coll Cardiol. 2017; 69:325-44.

7. Habib G, Lancellotti P, Antunes MJ, Bongiorni MG, Casalta JP, Del Zotti F, et al. ESC Guidelines for the management of infective endocarditis: The Task Force for the Management of Infective Endocarditis of the European Society of Cardiology (ESC). Endorsed by: European Association for Cardio-Thoracic Surgery (EACTS), the European Association of Nuclear Medicine (EANM) Eur Heart J. 2015;36(44):3075-128.

[8. Popa LE, Petresc B, Catana C, Moldovanu CG, Feier DS, Lebovici A, et al. Association between cardiovascular risk factors and coronary artery disease assessed using CAD-RADS classification: a crosssectional study in Romanian population. BMJ Open. 2020 10:e031799.

9. Bor DH, Woolhandler S, Nardin R, Brusch J, Himmelstein DU. Infective endocarditis in the U.S., 1998-2009: A nationwide study.
PLoS ONE. 2013;8(3):e60033.

10. Thornhill MH, Dayer MJ, Forde JM, Corey GR, Hock G, Chu VH, et al. Impact of the NICE guideline recommending cessation of antibiotic prophylaxis for prevention of infective endocarditis: before and after study. BMJ. 2011;342:d2392.

11. Baddour LM, Cha YM, Wilson WR. Infections of cardiovascular implantable electronic devices. N Engl J Med. 2012; 367:842-9.

12. Hoen B, Alla F, Selton-Suty C, Beguinot I, Bouvet A, Briançon S, et al. Changing profile of infective endocarditis: results of a 1-year survey in France. JAMA. 2002; 288(1):75-81.

13. Flachskampf FA, Wouters PF, Edvardsen T, Evangelista A, Habib G, Hoffman $P$, et al. Recommendations for transoesophageal echocardiography: EACVI update 2014. Eur Heart J Cardiovasc Imaging. 2014;15:353-365

14. Castiñeira-Busto M, Abu-Assi E, Martínez-Monzonis A, Peña-Gil C, Raposeiras-Roubin S, González-Juanatey JR. Predicting the risk of systemic septic embolism in patients with infective endocarditis. Rev Esp Cardiol. 2015; 68(1):70-81.

15. Kang DH, Kim YJ, Kim SH, Sun BJ, Kim DH, Yun SC, et al. Early surgery versus conventional treatment for infective endocarditis. N Engl J Med. 2012; 366:2466-73.

16. Molnar A, Beyer R, Florian S, Muresanu DF, Trifan C, Muresan I, et al. Drainage of cerebral abscesses prior to valve replacement in stable patients with acute left-sided infective endocarditis. CNS \& Neurological Disorders Drug Targets. 2015;14(4):534-9.

17. Snygg-Martin U, Gustafsson L, Rosengren L, Alsio A, Ackerholm P, Andersson $\mathrm{R}$, et al. Cerebrovascular complications in patients with left-sided infective endocarditis are common: a prospective study using magnetic resonance imaging and neurochemical brain damage markers. CID. 2008;47:23-30.

18. Anchidin OI, Nemes A, Molnar A, Rosianu A, Rosianu SH, Pop D. Are cardiovascular rehabilitation programs implemented in young patients with acute coronary syndromes following revascularization procedures? Balneo Research Journal. 2020;11(2):133-40.

19. Chu VH, Cabell CH, Benjamin DK, Jr, Kuniholm EF, Fowler VG, Jr, John Engemann J, et al. Early predictors of in-hospital death in infective endocarditis. Circulation. 2004;109:1745-9.

20. Hasbun R, Vikram HR, Barakat LA, Buenconsejo J, Quagliarello VJ. Complicated left-sided native valve endocarditis in adults: risk classification for mortality. JAMA. 2003;289:1933-40.

21. Chirillo F, Scotton P, Rocco F, Rigoli R, Borsatto F, Pedrocco A, et al. Impact of a multidisciplinary management strategy on the outcome of patients with native valve infective endocarditis. Am J Cardiol. 2013;112:1171-6.

22. Botelho-Nevers E, Thuny F, Casalta JP, Richet H, Gouriet F, Collart $F$, et al. Dramatic reduction in infective endocarditis related mortality with a management-based approach. Arch Intern Med. 2009;169:1290-8.

23. Kang DH, Kim YJ, Kim SH, Sun BJ, Kim DH, Yun SC, et al. Early surgery versus conventional treatment for infective endocarditis. N Engl J Med. 2012; 366:2466-73. 